\title{
GENERALISASI FUNGSI AIRY SEBAGAI SOLUSI ANALITIK PERSAMAAN SCHRODINGER NONLINIER
}

\author{
Lukman Hakim¹) dan Ari Kusumastuti2) \\ 1)Mahasiswa Pascasarjana Jurusan Matematika Universitas Brawijaya Malang \\ 2)Jurusan Matematika UIN Maulana Malik Ibrahim Malang \\ e-mail: bedek_me@yahoo.com
}

\begin{abstract}
ABSTRAK
Persamaan Schrodinger adalah persamaan diferensial parsial nonlinier yang menginterpretasikan pergerakan suatu partikel atau atom. Penelitian ini berupaya untuk memperoleh analisis konstruksi bentuk umum solusi ananalitik persamaan Schrodinger nonlinier dengan fungsi Airy. Fungsi Airy adalah solusi persamaan diferensial Airy, adapun langkah pertama adalah manipulasi bentuk persamaan Schrodinger nonlinier menjadi bentuk persamaan Airy dengan menerapkan transformasi Fourier. Dengan demikian didapatkan solusia nanalitik persamaan Airy dengan generalisasi fungsi Airy. Dan langkah selanjutnya adalah menerapkan invers dari transformasi Fourier yang digunakan untuk memdapatkan solusi analitik bagi persamaan Schrodinger nonlinier, dalam hal ini diberikan kondisi awal bilangan kompleks pada invers transformasi Fourier, yaitu $U(\omega, t)=\omega^{2}+i t$.

Adapun hasil dari penelitian ini adalah solusi bagi persamaan Schrodinger nonlinier ketika pangkat dari modulusnya di analisis dengan bentuk ganjil dan genap memberikan bentuk solusi yang sama yaitu:
\end{abstract} $u(x, t)=\frac{1}{\pi} \int_{0}^{\infty} \cos \left(\frac{\omega^{3}}{3}-i \omega^{2}\right) d \omega$

Sedangkan ketika di analisis hingga dimensi $n$ maka didapatkan generalisasi fungsi Airy sebagai berikut: $u\left(x_{1}, x_{2}, x_{3}, \ldots, x_{n}, t\right)=$

$$
\frac{1}{\pi} \int_{0}^{\infty} \cos \left(\begin{array}{c}
\frac{\omega^{3}}{3}+\left(t+1+\sum_{a=3}^{n} x_{a}\right)^{2} \omega^{3}+\left(t+x_{2}+1+\sum_{a=4}^{L L} x_{a}\right)^{2} \grave{\mathrm{u}}^{3}+\cdots+ \\
+\left(t+\sum_{a=2}^{n-1} x_{a}+1\right)^{2} \grave{\mathrm{u}}^{3}-i\left(t+\sum_{a=2}^{n} x_{a}\right)^{2} \grave{\mathrm{u}}^{2} \\
-A\left(\frac{1}{(2 ð)^{n}} \int_{-\infty}^{\infty} \int_{-\infty}^{\infty} \int_{-\infty}^{\infty} \ldots \int_{-\infty}^{\infty} e^{i \mathrm{u}\left(\sum_{a=2}^{n} x_{a}+t\right)} d x_{n}\right)
\end{array}\right) d \grave{u}
$$

Kata Kunci: Persamaan Schrodinger Nonlinier, Persamaan Airy, Fungsi Airy, Transformasi Fourier dan Invers Transformasi Fourier.

\section{PENDAHULUAN}

Persamaan diferensial parsial (PDP) adalah kajian ilmu matematika yang berkaitan langsung dengan kehidupan manusia karena persamaan diferensial parsial dapat digunakan untuk menterjemahkan fenomena alam menjadi suatu persamaan yang sistematis dan logis (Purwanto, 2003).

Secara definitif, persamaan diferensial adalah persamaan yang mengandung fungsifungsi turunan, baik turunan parsial maupun turunan biasa. Dan dalam menyelesaikan persamaan diferensial secara analitik, biasanya terbatas pada persamaan-persamaan diferensial dengan bentuk tertentu dan biasanyahanya digunakanuntuk menyelesaikan persamaanpersamaan yang linier. Sedangkan persamaan diferensial nonlinier tidak mudah diselesaikan secara langsung, akan tetapi harus melalui transformasi-transformasi yang menjadikan persamaan nonlinier menjadi persamaan yang linier (Ross, 1984).

Selain sebagai alat untuk memodelkan masalah, maka persamaan diferensial parsial juga menjadi alat yang digunakan untuk menyelesaikan permasalahan matematika fisika, matematika kimia dan fenomena yang ada di alam (Purwanto, 2003). Misalnya, fenomena alam yang terjadi di laut yaitu adanya gerakan partikel di bawah laut yang menimbulkan gelombang yang disebut dengan gelombang internal. Gelombang ini terjadi karena terdapat perbedaan rapat massa pada setiap lapisan laut dan perbedaan rapat massa disebabkan oleh perbedaan kadar garam dan temperatur dari setiap lapisan laut, selain di laut pergerakan partikel dapat juga terjadi pada medan kuantum. Dalam hal ini persamaan diferensial parsial yang 
menggambarkan pergerakan elektron pada medan kuantum adalah model persamaan Schrodinger (Sudirham dan Utari, 2010).

Persamaan Schrodinger adalah persamaan diferensial parsial yang menggambarkan bagaimana pergerakan suatu partikel khususnya partikel elektron. Dalam ilmu fisika, persamaan Schrodinger diperkenalkan oleh fisikawan Erwin Schrodinger pada tahun 1925 dan dijelaskan juga bagaimana hubungan antara ruang dan waktu pada sistem mekanika kuantum. Persamaan ini sangat penting seperti halnya persamaan Newton yang menjadi dasar berkembangnya keilmuan Fisika, dan sedangkan persamaan Schrodinger menjadi dasar berkembangnya ilmu Fisika modern yang berkenaan dengan mekanika kuantum (Sudirham dan Utari, 2010).

Fungsi Airy adalah suatu fungsi yang menjadi solusi bagi persamaan diferensial Airy. Adapun bentuk persamaan Airy adalah $y^{\prime \prime}-x y=0$ dan solusinya disebut dengan fungsi Airy. Selanjutnya diberikan penjelasan bahwa fungsi Airy adalah salah satu bentuk model penyelesaian persamaan diferensial Schrodinger. Dengan demikian asumsi-asumsi yang harus dipenuhi persamaan Schrodinger agar dapat diselesaikan dengan fungsi Airy adalah persamaan Schrodinger harus dikontruks menjadi model persamaan Airy, kemudian diselesaikan dan didapatkan fungsi Airy (Valle dan Manuael, 2004).

Berdasarkan pemaparan di atas peneliti ini bertujuan untuk memaparkan analisis bentuk generalisasi fungsi Airy sebagai solusi analitik bagi persamaan Schrodinger nonlinier. Dan dalam penelitian ini dibatasi pada generalisasi bentuk umum solusi ketika pangkat dari modulus persamaan Schrodinger nonlinier dianalisis dengan bentuk pangkat ganjil dan genap, dan generalisasi bentuk umum solusi ketika dimensi dari persamaan Schrodinger nonlinier dinaikkan hingga dimensi $n$.

Adapun metode penelitian yang digunakan pada penelitian ini adalah analisis brownian motion persamaan Schrodinger nonlinier, transformasi persamaan Schrodingernonlinier ke dalam bentuk persamaan Airy dengan transformasi Fourier, menyelesaikan persamaan Airy sehingga solusi yang disebut dengan fungsi Airy, menerapkan invers transformasi Fourier dan memberikan kondisi awal sehingga didapatkan solusi persamaan Schrodinger nonlinier.

\section{KAJIAN PUSTAKA}

\section{Persamaan Diferensial Parsial}

Persamaan diferensial adalah persamaan yang memuat turunan satu atau lebih dari variabel tak bebas terhadap satu atau lebih variabel bebas.Berdasarkan jumlah variabel bebasnya, persamaan diferensial dikelompokkan menjadi persamaan diferensial biasa (PDB) atau OrdinaryDifferential Equation (ODE) dan persamaan diferensial parsial (PDP) atau PartialDifferential Equation (PDE) (Ross, 1984).

Persamaan diferensial parsial (PDP) adalah persamaan diferensial yang memuat turunan parsial satu atau lebih dari variabel tak bebas terhadap satu atau lebih variabel bebas (Ross, 1984).

\section{Orde Persamaan Diferential Parsial}

Ordo/orde suatu persamaan diferensial adalah pangkat turunan tertinggi yang muncul dalam persamaan diferensial (Stewart, 2003). Sedangkan tingkat derivatif parsial tertinggi merupakan tingkat dari persamaan differensial parsial tersebut dan pangkat tertinggi dari orde tertinggi merupakan derajat dari persamaan differensial tersebut (Soeharjo,1996).

\section{Persamaan Schrodinger}

Persamaan Schrodinger diajukan pada tahun 1925 oleh ahli fisika yaitu Erwin Schrodinger (1887-1961).Persamaan ini pada awalnya merupakan jawaban dari dualitas partikel gelombang yang lahir dari gagasan de Broglie yang menggunakan persamaan kuantisasi cahaya Planck dan prinsip fotolistrik Einstein dalam menentukan kuantisasi pada orbit elektron.

Selain Erwin Schrodinger ada dua orang fisikawan lainnya yang mengajukan teorinya yaitu Werner Heisenberg dengan mekanika matriks dan Paul Dirac dengan aljabar kuantum.Ketiga teori ini merupakan teori kuantum lengkap yang berbeda dan dikerjakan secara terpisah namun ketiganya setara.Teori Erwin Schrodinger kemudian lebih sering digunakan dengan alasan rumusan matematisnya yang relatif sederhana dan lebih aplikatif (Sudirham dan Utari, 2010).

Persamaan Schrodinger banyak kegunaannya dan karena penerapannya mencapai ketelitian sangat tinggi dan akurat.Penggunaan persamaan Schrodinger pada sistem fisis memungkinkan untuk memberikan ketelitian yang sangat tinggi dan berdasarkan penelitian terbaru bahwa persamaan Schrodinger nonlinier mempunyai peluang hingga tingkatan nano.Sehingga penerapan ini menghasilkan ramalan-ramalan baru misalnya, penemuan positron yang merupakan anti materi dari elektron.

Selanjutnya persamaan Schrodinger menjadi landasan berkembangnya keilmuan di bidang mekanika kuantum dan dewasa ini persamaan Schrodinger telah diterapkan di berbagai bidang 
fisika yaitu fisika matematika, optik tidak linier, sistem kuantum partikel banyak, fisika plasma dan superkonduktivitas. Dan pada penelitian ini dikhususkan untuk mempelajari solusi analitik persamaan Schrodinger nonlinear menggunakan generalisasi fungsi Airy, adapun bentuk umum persamaan Schrodinger nonlinier adalah (Polyanin dan Zaitsev, 2004):

$\frac{\partial u(x, t)}{\partial t}+\frac{\partial^{2} u(x, t)}{\partial x^{2}}+A|u(x, t)|^{n} u(x, t)=0$

Dimana:

$$
\begin{array}{ll}
u(x, t) & \text { : fungsi bernilai kompleks } \\
t & : \text { waktu } \\
A & : \text { bilangan bernilai riil } \\
|u|^{2} & : u \bar{u} \\
\bar{u} & : \text { konjugat fungsi } u(x, t)
\end{array}
$$

\section{Integral Fourier}

Misalkan didefinisikan fungsi $f_{p}(x)$ suatu fungsi dengan periode $2 p$ maka fungsi ini dapat diinterpretasikan ke dalam bentuk deret Fourier (Agarwal dan O'regan, 2009), yaitu:

$f_{p}(x)=\frac{a_{0}}{2}+\sum_{n=0}^{\infty}\left(a_{n} \cos \grave{\mathrm{u}}_{n} x+b_{n} \sin \grave{\mathrm{u}}_{n} x\right)$

$\grave{\mathrm{u}}_{n}=\frac{n ð}{p}$

$a_{n}=\frac{1}{p} \int_{-p}^{p} f_{p}(t) \cos \grave{\mathrm{u}}_{n} t d t, \quad n \geq 0$

$b_{n}=\frac{1}{p} \int_{-\uparrow}^{p} f_{p}(t) \sin \grave{\mathrm{u}}_{n} t d t, \quad n \geq 1$

Dengan demikian didapatkan nilai dari $\frac{a_{0}}{2}$ adalah

$\frac{a_{0}}{2}=\frac{1}{2 p} \int_{-p}^{p} f_{p}(t) t d t$

Nilai $a_{n} \cos \grave{u}_{n} x$ adalah

$a_{n} \cos \grave{u ̀}_{n} x$

$=\cos \grave{\mathrm{u}}_{n} x\left(\frac{1}{p} \int_{-p}^{p} f_{p}(t) \cos \grave{\mathrm{u}}_{n} t d t\right)$

Nilai $b_{n} \sin \grave{\mathrm{u}}_{n} x$ adalah

$b_{n} \sin \grave{\mathrm{u}}_{n} x$

$=\sin \grave{\mathrm{u}}_{n} x\left(\frac{1}{p} \int_{-p}^{p} f_{p}(t) \sin \grave{\mathrm{u}}_{n} t d t\right)$

Substitusi persamaan (3), (4) dan (5) ke persamaan (2), dengan $p \rightarrow \infty$ maka didapatkan

$f_{p}(x)=\frac{1}{2 p} \int_{-p}^{p} f_{p}(t) t d t$

$$
+\frac{1}{p} \sum_{n=1}^{\infty}\left[\begin{array}{c}
\cos \grave{\mathrm{u}}_{n} x \int_{-p}^{p} f_{p}(t) \cos \grave{\mathrm{u}}_{n} t d t \\
+\sin \grave{\mathrm{u}}_{n} x \int_{-p}^{p} f_{p}(t) \sin \grave{\mathrm{u}}_{n} t d t
\end{array}\right]
$$

Kemudian didefinisikan $\Delta$ ù sebagai perubahan frekuensi sudut, yaitu:

$\Delta \grave{\mathrm{u}}=\grave{\mathrm{u}}_{n+1}-\grave{\mathrm{u}}_{n}=\frac{(n+1) ð}{p}-\frac{n ð}{p}=\frac{\text { ð }}{p}$

Maka diperoleh dari persamaan (7) adalah

$\frac{1}{p}=\frac{\Delta \mathrm{u}}{\partial}$

Dengan menerapkan persamaan (8) pada persamaan (6) maka didapatkan

$f_{p}(x)=\frac{1}{2 p} \int_{-p}^{p} f_{p}(t) t d t+$

$\frac{1}{\bar{\partial}} \sum_{n=1}^{\infty}\left[\begin{array}{c}\left(\cos \grave{\mathrm{u}}_{n} x\right) \Delta \mathrm{u} \int_{-p}^{p} f_{p}(t) \cos \grave{\mathrm{u}}_{n} t d t \\ +\left(\text { in } \grave{\mathrm{u}}_{n} x\right) \Delta \mathrm{u} \int_{-p}^{p} f_{p}(t) \sin \grave{\mathrm{u}}_{n} t d t\end{array}\right]$

Karena $\quad p \rightarrow \infty$ maka $\lim _{p \rightarrow \infty} f_{p}(x)=f(x)$ sehingga nilai dari $\frac{1}{p} \rightarrow 0$ dan mengakibatkan nilai dari $\frac{1}{2 p} \int_{-p}^{p} f_{p}(t) t d t \approx 0$, begitu juga nilai $\Delta \grave{u}=\frac{\delta}{p} \rightarrow 0$. Suatu deret adalah jumlah dari suku demi suku dan dikarenakan suku menuju tak hingga maka didekati dengan limit sehingga berupa suatu luasan kurva dari persamaan. Berdasarkan definisi integral Reimann bahwa limit dari deret infinit ekuivalen dengan integral yang mempunyai batas bawah 0 dan batas atas $\infty$ (Purcell dan Varberg, 1999). Dengan demikian persamaan (9) yang semula berupa deret infinit menjadi definisi suatu integral (Agarwal dan O'regan, 2009),

$f(x)=$

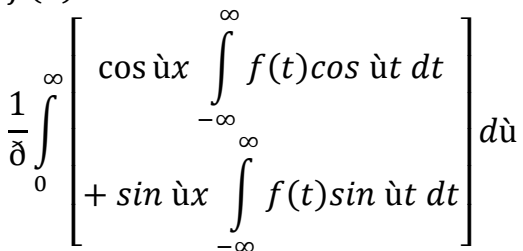

Persamaan (10) disebut dengan integral Fourier.

\section{Transformasi Fourier}

Pandang persamaan (10), yaitu $f(x)=$

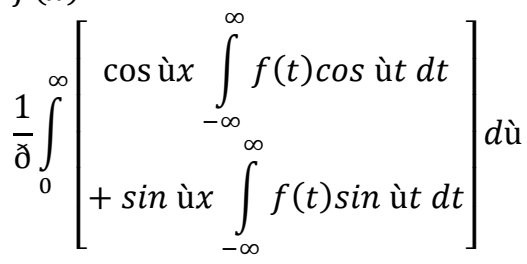


$=\frac{1}{\partial} \int_{0}^{\infty}\left[\int_{-\infty}^{\infty} f(t) \cos (\grave{u} x-\grave{u} t) d t\right] d \grave{u}$

Persamaan (11) dapat dinyatakan dalam bentuk yang ekuivalen sebagai berikut:

$f(x)=$

$\frac{1}{2 ð} \int_{-\infty}^{\infty}\left[\int_{-\infty}^{\infty} f(t) \cos (\grave{u} x-\grave{u ̀} t) d t\right] d \grave{u}$

Analog dengan persamaan (12) maka dapat dibentuk persamaan baru yang valid yaitu

$\frac{1}{2 ð} \int_{-\infty}^{\infty}\left[\int_{-\infty}^{\infty} f(t)(i) s-n(\grave{u} x-\grave{u ̀} t) d t\right] d \grave{u}$

$$
=0
$$

Karena fungsi $\sin x$ adalah fungsi ganjil maka nilai dari persamaan (13) adalah nol, dikarenakan integral dari $-\infty$ sampai $\infty$ pada fungsi ganjil menghasilkan nilai nol maka persamaan (13) benar (Agarwal dan O'regan, 2009). Selanjutnya kombinasi dari persamaan (12) dan (13) menghasilkan

$f(x)=$

$\frac{1}{2 ð} \int_{-\infty}^{\infty}\left[\int_{-\infty}^{\infty} f(t) \cos (\grave{u} x-\grave{u ̀} t) d t\right] d \grave{u}$

$+\frac{1}{2 ð} \int_{-\infty}^{\infty}\left[\int_{-\infty}^{\infty} f(t) i \sin (\grave{u} x-\grave{u} t) d t\right] d \grave{u}$

$=\frac{1}{2 ð} \int_{-\infty}^{\infty}\left[\int_{-\infty}^{\infty} f(t)\left(\begin{array}{c}\cos (\grave{u} x-\text { ù } t) \\ +i \sin (\grave{u} x-\grave{u} t)\end{array}\right) d t\right] d \grave{u}$

Berdasarkan rumus Euler maka persamaan (14) menjadi

$$
\begin{aligned}
f(x) & =\frac{1}{2 ð} \int_{-\infty}^{\infty} \int_{-\infty}^{\infty} f(t) e^{i(\grave{u} x-\grave{u} t)} d t d \grave{u} \\
& =\frac{1}{2 ð} \int_{-\infty}^{\infty} \int_{-\infty}^{\infty} f(t) e^{i \grave{u}(x-t)} d t d \grave{u}
\end{aligned}
$$

Persamaan (15) dapat diuraikan menjadi

$f(x)=\frac{1}{2 ð} \int_{-\infty}^{\infty}\left[\int_{-\infty}^{\infty} f(t) e^{-i \grave{u} t} d t\right] e^{i u ̀ x} d \grave{u}$

Selanjutnya integral yang di dalam kurung dari persamaan (16) disimbolkan dengan $F($ ù) yang disebut dengan transformasi Fourier dari $f(x)$, yaitu:

$$
F(\grave{u})=\int_{-\infty}^{\infty} f(t) e^{i \text { 妾 } t} d \grave{u}
$$

\section{Fungsi Airy}

Pandang persamaan diferensial orde dua berikut:

$\frac{d^{2} y(x)}{d x^{2}}-x y(x)=0$

Selanjutnya persamaan (18) disebut Persamaan Airy dan solusi persamaan Airy disebut dengan fungsi Airy. Solusi persamaan (18) akan mudah dicari dengan menerapkan transformasi Fourier, jika didefinisikan $Y(\grave{u})$ sebagai transformasi Fourier dari $y(x)$, yaitu:

$Y(\grave{u})=\int_{-\infty}^{\infty} e^{-i u ̀ x} y(x) d x$

Jika persamaan (19) diturunkan dua kali terhadap $x$ maka didapatkan

$$
\begin{aligned}
& \frac{d^{2} Y(\grave{\mathrm{u}})}{d x^{2}}=\frac{d^{2}}{d x^{2}}\left(\int_{-\infty}^{\infty} e^{-i \grave{x} x} y(x) d x\right) \\
& =\int_{-\infty}^{\infty} e^{-i \mathrm{ùx}} y^{\prime \prime}(x) d x
\end{aligned}
$$

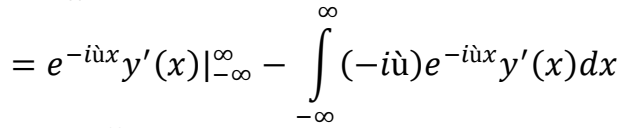

$$
\begin{aligned}
& =i \mathrm{u} \int_{-\infty}^{\infty} e^{-i \grave{u} x} y^{\prime}(x) d x
\end{aligned}
$$

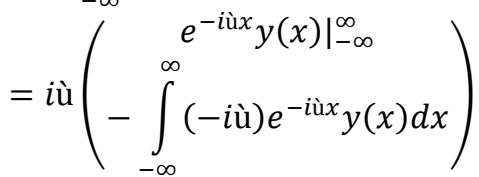

$$
\begin{aligned}
& =-\grave{\mathrm{u}}^{2} Y(\grave{\mathrm{u}}(x))
\end{aligned}
$$

Selanjutnya persamaan (19) diturukan terhadap ù dengan langkah berikut:

$$
\begin{aligned}
& \frac{d Y(\grave{\mathrm{u}})}{d \grave{\mathrm{u}}}=\frac{d}{d \grave{\mathrm{u}}}\left(\int_{-\infty}^{\infty} e^{-i \mathrm{ùx}} y(x) d x\right) \\
& =-i x \int_{-\infty}^{\infty} e^{-i \grave{x} x} y(x) d x \\
& =-i x Y^{-\infty}(\grave{u}(x))
\end{aligned}
$$

Maka didapatkan

$\frac{d Y(\grave{\mathrm{u}})}{d \grave{\mathrm{u}}}=-i x Y(\grave{\mathrm{u}}(x))$

Berdasarkan persamaan (21) maka didapatkan maka diperoleh

$i \frac{d Y(\grave{\mathrm{u}})}{d \grave{\mathrm{u}}}=x Y(\grave{\mathrm{u}})$

Berdasarkan persamaan (20) dan (22) maka didapatkan modifikasi persamaan (18), adalah

$$
\begin{aligned}
& -\grave{\mathrm{u}}^{2} Y(\mathrm{u})=i \frac{d Y(\grave{\mathrm{u}})}{d \grave{\mathrm{u}}} \\
& i \grave{\mathrm{u}}^{2} Y(\grave{\mathrm{u}})=\frac{d Y(\grave{\mathrm{u}})}{d \grave{\mathrm{u}}} \\
& i \grave{\mathrm{u}}^{2} d \mathrm{u}=\frac{d Y(\grave{\mathrm{u}})}{Y(\grave{\mathrm{u}})} \\
& \frac{\grave{\mathrm{u}}^{3}}{3} i=\ln Y(\grave{\mathrm{u}}) \\
& Y(\grave{\mathrm{u}})=e^{\frac{\grave{\mathrm{u}}^{3}}{3} i}
\end{aligned}
$$


Langkah selanjutnya adalah menggunakan invers transformasi Fourier untuk mendapatkan solusi dalam bentuk $y(x)$, yaitu:

$y(x)=\frac{1}{2 ð} \int_{-\infty}^{\infty} e^{i u ̀ x} Y(\grave{u}) d \grave{u}$

Substitusi persamaan (23) pada persamaan (24) maka didapatkan

$y(x)=\frac{1}{2 ð} \int_{-\infty}^{\infty} e^{i\left(\grave{\mathrm{u}} x+\frac{\grave{\mathrm{u}}^{3}}{3}\right)} d \mathrm{ù}$

Berdasarkan rumus Euler, maka didapatkan

$$
\begin{aligned}
e^{i\left(\grave{\mathrm{u}} x+\frac{\grave{\mathrm{u}}^{3}}{3}\right)} & =\cos \left(\grave{\mathrm{u}} x+\frac{\grave{\mathrm{u}}^{3}}{3}\right) \\
& +i \sin \left(\grave{\mathrm{u}} x+\frac{\grave{\mathrm{u}}^{3}}{3}\right)
\end{aligned}
$$

Dengan demikian diperoleh

$$
y(x)=\frac{1}{2 ð}\left[\int_{-\infty}^{\infty}+\int_{-\infty}^{\infty} i \sin \left(\grave{\mathrm{u}} x+\frac{\grave{\mathrm{u}}^{3}}{3}\right) d \grave{u}\right]
$$

Karena fungsi $\sin x$ adalah fungsi ganjil maka persamaan (27) menjadi

$y(x)=\frac{1}{2 ð} \int_{-\infty}^{\infty} \cos \left(\grave{\mathrm{u}} x+\frac{\grave{\mathrm{u}}^{3}}{3}\right) d \mathrm{ù}$

Karena fungsi $\cos x$ adalah fungsi genap maka persamaan (28) menjadi

$y(x)=\frac{1}{\partial} \int_{0}^{\infty} \cos \left(\grave{\mathrm{u}} x+\frac{\grave{\mathrm{u}}^{3}}{3}\right) d \grave{\mathrm{u}}$

Karena persamaan (29) adalah solusi bagi persamaan Airy (18) maka disebut dengan fungsi Airy dan kemudian fungsi Airy disimbolkan dengan $A i(x)$, yaitu:

$$
\operatorname{Ai}(x)=\frac{1}{\partial} \int_{0}^{\infty} \cos \left(\grave{\mathrm{u}} x+\frac{\mathrm{ù}^{3}}{3}\right) d \grave{u}
$$

(Oliver dan Manuael, 2004).

\section{PEMBAHASAN}

\section{Analisis Brownion Motion Persamaan Schrodinger Nonlinier}

Suatu gelombang pada dasarnya adalah pergerakan bebas partikel-partikel yang merambat ke segala arah dan pergerakannya dipengaruhi oleh energi masing-masing partikel, akan tetapi setiap partikel berpeluang sama untuk bergerak ke segala arah. Persamaan Schrodinger adalah salah satu model gelombang yang interpretasinya banyak diterapkan pada mekanika kuantum. Adapun asumsi yang mendasari persamaan Schrodinger adalah adanya pergerakan acak pertikel dan setiap partikel mempunyai peluang gerak yang sama baik ke kanan maupun ke kiri karena pergerakan gelombangnya diasumsikan bergerak ke kanan dan ke kiri.

Dalam buku yang berjudul "Partial Differential Equations of Applied Mathematics" Erich Zauderer menyebutkan bahwa pergerakan suatu partikel dapat diinterpretasikan dalam bentuk distribusi probabilitas yang menyatakan bahwa probabilitas partikel di $x$ pada saat $t+\hat{o}$ sama dengan probabilitas partikel di $x$-ä pada saat $t$ dikalikan dengan probabilitas ç yang berpindah ke kanan ditambah dengan probabilitas partikel di $x+\ddot{a}$ pada saat $t$ dikalikan dengan probabilitasî yang berpindah ke kiri, sehingga pergerakan partikel dapat dinyatakan dengan persamaan matematis, yaitu: $u(x, t+\hat{o})=c ̧ u(x-\ddot{a}, t)+\hat{\imath} u(x+\ddot{a}, t)$ Berdasarkan ekspansi deret Taylor (2. 22) maka didapatkan sistem persamaan dari persamaan (3.1) adalah

$$
\left\{\begin{array}{c}
u(x, t+\hat{o})=u(x, t)+\hat{o} u_{t}(x, t) \\
u(x-\ddot{a}, \hat{o})=u(x, t)-\ddot{a} u_{x}(x, t)+\frac{1}{2} \ddot{a}^{2} u_{x x}(x, t) \\
u(x+\ddot{a}, \hat{o})=u(x, t)+\ddot{a} u_{x}(x, t)+\frac{1}{2} \ddot{a}^{2} u_{x x}(x, t)
\end{array}\right.
$$

Selanjutnya substitusi sistem persamaan (32) pada persamaan (31) dan didapatkan

$$
\left.\begin{array}{c}
u(x, t)+\hat{o} u_{t} u(x, t)=c\left[\begin{array}{c}
u(x, t)-\ddot{a} u_{x}(x, t) \\
+\frac{1}{2} \ddot{a}^{2} u_{x x}(x, t)
\end{array}\right] \\
+\hat{\imath}\left[u(x, t)+\ddot{a} u_{x}(x, t)+\frac{1}{2} \ddot{a}^{2} u_{x x}(x, t)\right.
\end{array}\right]
$$

Karena pergerakan partikel adalah kejadian peluang maka nilai dari pergerakan peluang ke kanan dan ke kiri yaitu: $(c+\hat{\imath}) \approx 1$ maka persamaan (33) menjadi

$\hat{o} u_{t}(x, t)=(-c+\hat{\imath}) \ddot{a} u_{x}(x, t)+\frac{1}{2} \ddot{a}^{2} u_{x x}(x, t)$

Jika masing-masing dari ruas persamaan (34) dibagi dengan $\hat{o}$ maka didapatkan

$u_{t}(x, t)=\frac{(-c+\hat{\imath})}{\hat{o}} \ddot{a} u_{x}(x, t)+\frac{1}{2} \frac{\bullet}{\hat{o}} u_{x x}(x, t)$

Jika ruas kanan dipindah ke ruas kiri maka persamaan (35) menjadi

$u_{t}(x, t)-\frac{(-c+\hat{\imath}) \ddot{a}}{\hat{o}} u_{x}(x, t)-\frac{\ddot{a}^{2}}{2 \hat{o}} u_{x x}(x, t)=0$

Kemudian persamaan (36) dikenal dengan persamaaan difusi satu dimensi, dengan pergerakan gelombangnya ke kanan dan ke kiri. Jika diasusmsikan nilai

$\frac{(-c+\hat{\imath}) \ddot{a}}{\hat{o}} \approx 0$

Maka didapatkan persamaan difusi satu dimensi dengan mengabaikan kecepatan pergerakan partikel, yaitu:

$\frac{\partial u(x, t)}{\partial t}-\left(\frac{\ddot{a}^{2}}{2 \hat{o}}\right) \frac{\partial^{2} u(x, t)}{\partial x^{2}}=0$

Jika ruas kiri dari persamaan (37) ditambah suatu fungsi dengan bentuk $A|u(x, t)|^{n} u(x, t)$ maka didapatkan 
$\frac{\partial u(x, t)}{\partial t}-\left(\frac{\ddot{a}^{2}}{2 \hat{o}}\right) \frac{\partial^{2} u(x, t)}{\partial x^{2}}+A|u(x, t)|^{n} u(x, t)=0$

Jika diasumsikan nilai dari $\frac{\ddot{a}^{2}}{2 \hat{o}} \approx-1$ maka persamaan (38) menjadi

$\frac{\partial u(x, t)}{\partial t}+\frac{\square^{2} u(x, t)}{\partial x^{2}}+A|u(x, t)|^{n} u(x, t)=0$

Dimana $A$ adalah konstanta riil dan bentuk persamaan (39) disebut dengan persamaan Schrodinger nonlinier satu dimensi.

\section{Solusi Analitik Persamaan Schrodinger Nonlinier dengan Generalisasi Fungsi Airy}

Meninjau persamaan Schrodinger nonlinier (39), yaitu:

$$
\frac{\partial u(x, t)}{\partial t}+\frac{\partial^{2} u(x, t)}{\partial x^{2}}+A|u(x, t)|^{n} u(x, t)=0
$$

Dimana $A$ adalah konstanta real dan $|u|^{2}=u \bar{u}$, untuk $\bar{u}$ adalah konjugat dari $u$ suatu fungsi kompleks.

Kasus I: jika $n$ genap maka persamaan (40) dapat dinyatakan sebagai berikut:

$\frac{\partial u(x, t)}{\partial t}+\frac{\partial^{2} u(x, t)}{\partial x^{2}}+A|u(x, t)|^{2 m} u(x, t)=0$

Selanjutnya, jika $m=1$ maka persamaan

menjadi

$$
\frac{\partial u(x, t)}{\partial t}+\frac{\partial^{2} u(x, t)}{\partial x^{2}}+A|u(x, t)|^{2} u(x, t)
$$

Jika persamaan (42) ditransformasi dengan transformasi Fourier, dan transformasi Fourier yang digunakan adalah

$U(\grave{u}(x, t), t)=\int_{-\infty}^{\infty} e^{-i \grave{u} t} u(x, t) d t$

Maka invers trasformasi Fourier dari $U(\grave{u}, t)$ adalah $u(x, t)$ dan dapat dinyatakan sebagai berikut:

$u(x, t)=\frac{1}{2 \succsim} \int_{-\infty}^{\infty} e^{-i \grave{u} t} U(\grave{u}, t) d \grave{u}$

Persamaan (43) memberikan makna bahwa bentuk $u(x, t)$ ditranformasi menjadi bentuk $U(\grave{u}(x, t), t)$ yang secara fisis mentransformasi domain dari bentuk spasial ke dalam bentuk frekuensi, dan kemudian penulisan $U(\grave{u}(x, t), t)$ akan disingkat dengan $U(\grave{u}, t)$. Kemudian, jika persamaan (43) diturunkan terhadap $t$ maka didapatkan

$$
\begin{aligned}
& \frac{\partial U(\grave{\mathrm{u}}, t)}{\partial t}=\int_{-\infty}^{\infty} e^{-i \mathrm{ù} \text { 壏 }} \frac{\partial u(x, t)}{\partial t} d t \\
& =\left.e^{-i u ̀ t} u(x, t)\right|_{-\infty} ^{\infty} \\
& -\int_{-\infty}^{\infty}(-i u ̀) e^{-i u ̀ t} u(x, t) d t \\
& =i \mathrm{u} U(\grave{u}, t)
\end{aligned}
$$

Memandang transformasi untuk $|u(x, t)|^{2}$ adalah $|U(\mathrm{u}, t)|^{2}$ maka berdasarkan definisi pada analisis kompleks didapatkan bahwa

$|U(\grave{u}, t)|^{2}=U($ ù, $t) \cdot \bar{U}(\grave{u}, t)$

Kemudian dengan memandang persamaan (43) maka transformasi $|U(\grave{u}, t)|^{2}$ pada persamaan (46) dapat dinyatakan

$|U(\mathrm{ù}, t)|^{2}$

$=\left(\int_{-\infty}^{\infty} e^{-i u ̀ t} u(x, t) d t\right)\left(\int_{-\infty}^{\infty} e^{-i \grave{u} t} \bar{u}(x, t) d t\right)$

Berdasarkan persamaan (45) maka didapatkan modifikasi dari persamaan (42) adalah

$i \mathrm{ù} U(\grave{\mathrm{u}}, t)+\frac{\partial^{2} U(\grave{\mathrm{u}}, t)}{\partial x^{2}}+$

$A|U(\mathrm{u}, t)|^{2} U(\grave{u}, t)=0$

Bentuk sederhana persamaan (48) adalah

$\frac{\partial^{2} U(\grave{\mathrm{u}}, t)}{\partial x^{2}}=\left(-i \mathrm{u}-A|U(\grave{\mathrm{u}}, t)|^{2}\right) U(\grave{\mathrm{u}}, t)$

Misal $-i \mathrm{u}-A|U(\mathrm{u}, t)|^{2}=B$, maka persamaan (49) menjadi

$\frac{\partial^{2} U(\grave{u}, t)}{\partial x^{2}}=B U(\grave{u}, t)$

Analog dengan persamaan (18) maka solusi persamaan (50) adalah

$U(\grave{\mathrm{u}}, t)=\frac{1}{\partial} \int_{0}^{\infty} \cos \left(\frac{\grave{\mathrm{u}}^{3}}{3}+B \grave{\mathrm{u}}\right) d \mathrm{ù}$

Substitusi $B$ dengan $-i$ ù $-A \mid\left. U($ ù, $t)\right|^{2}$ maka didapatkan

$U(\grave{\mathrm{u}}, t)=\frac{1}{\partial} \int_{0}^{\infty} \cos \left(\frac{\grave{\mathrm{u}}^{3}}{3}+\left(\begin{array}{c}-i \mathrm{ù}- \\ A|U(\mathrm{ù}, t)|^{2}\end{array}\right) \mathrm{ù}\right) d \grave{\mathrm{u}}$

Substitusi $|U(\grave{u}, t)|^{2}$ dengan persamaan (47), maka persamaan (51) menjadi

$U(\grave{u}, t)=$

$\frac{1}{\bar{\partial}} \int_{0}^{\infty} \cos \left(\begin{array}{c}\frac{\grave{\mathrm{u}}^{3}}{3}-i \grave{\mathrm{u}}^{2}- \\ \left(\int_{-\infty}^{\infty} e^{-i \mathrm{ùt}} u(x, t) d t\right) \\ \left(\int_{-\infty}^{\infty} e^{-i \mathrm{ùt}} \bar{u}(x, t) d t\right)\end{array}\right) \mathrm{ù}$

Dengan demikian persamaan (52) adalah solusi persamaan Airy (50) dan untuk mendapatkan solusi persamaan Schrodinger (41) maka transformasi Fourier yang terdapat pada persamaan (43) harus diinverskan. Selanjutnya menggunakan invers transformasi Fourier (44) maka diperoleh solusi persamaan Schrodinger nonlinier adalah 


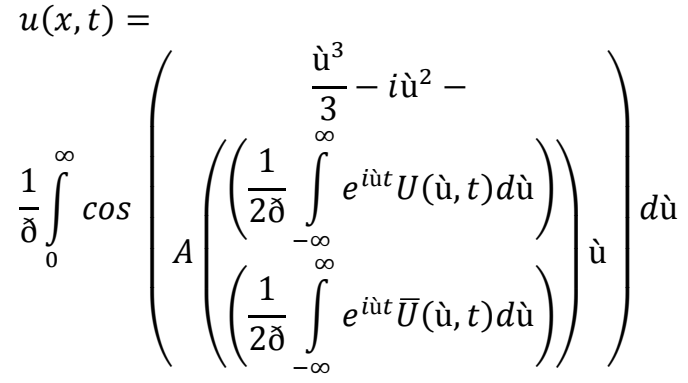

Selanjutnya pandang faktor berikut

$\frac{1}{2 ð} \int_{-\infty}^{\infty} e^{i \grave{u} t} U(\grave{u}, t) d \grave{u}$

Diberikan sebarang kondisi awal dan diasumsikan kondisi awalnya adalah fungsi komplek, maka dalam penelitian ini penulis mengambil kondisi awal sebagai berikut:

$U(\grave{\mathrm{u}}, t)=\grave{\mathrm{u}}^{2}+i t$

Sehingga saat $t=0$ didapatkan

$U(\grave{\mathrm{u}}, 0)=\grave{\mathrm{u}}^{2}+i 0=\grave{\mathrm{u}}^{2}$

Karena $\bar{U}$ adalah konjugat dari $U$ maka didapatkan

$\bar{U}(\grave{u}, t)=\grave{u}^{2}-i t$

Sehingga saat $t=0$ didapatkan

$U(\grave{\mathrm{u}}, 0)=\grave{\mathrm{u}}^{2}-i 0=\grave{\mathrm{u}}^{2}$

Berdasarkan persamaan (55) dan (57) maka persamaan (53) menjadi

$u(x, t)=$

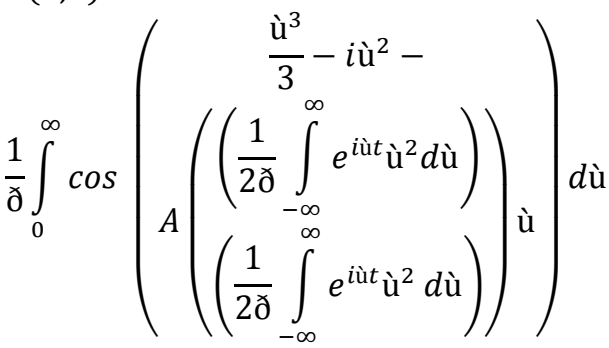

Kemudian pandang faktor berikut

$\frac{1}{2 ð} \int_{-\infty}^{\infty} e^{i \grave{u} t} \grave{u}^{2} d \grave{u}$

Berdasarkan sifat integral dan perhitungan integral biasa maka persamaan (59) menjadi

$\frac{1}{2 ð} \int_{-\infty}^{\infty} e^{i \grave{u} t} \grave{\mathrm{u}}^{2} d \grave{\mathrm{u}}=\frac{1}{ð i t^{3}}-\frac{1}{ð i t^{3}}=0$

Dengan demikian persamaan (58) menjadi

$u(x, t)=\frac{1}{\partial} \int_{0}^{\infty} \cos \left(\frac{\grave{\mathrm{u}}^{3}}{3}-i \grave{u}^{2}\right) d \grave{\mathrm{u}}$

Persamaan (60) adalah fungsi Airy yang menjadi solusi bagi persamaan Schrodinger nonlinier (42). Analog dengan proses pada persamaan (42) maka ketika mengambil nilai $m$ hingga $n$, maka solusi bagi persamaan berikut

$\frac{\partial u}{\partial t}(x, t)+\frac{\partial^{2} u}{\partial x^{2}}(x, t)+A|u(x, t)|^{2 m} u(x, t)=0$

adalah $u(x, t)=\frac{1}{\partial} \int_{0}^{\infty} \cos \left(\frac{\grave{\mathrm{u}}^{3}}{3}-i \grave{u ̀}^{2}\right) d \grave{\mathrm{u}}$

dengan demikian dapat disimpulkan bahwa bentuk umum fungsi Airy sebagai solusi persamaan Schrodinger nonlinier (42) adalah persamaan (61).

Kasus II: jika $n$ ganjil maka persamaan (40) dapat dinyatakan sebagai berikut:

$\frac{\partial u(x, t)}{\partial t}+\frac{\partial^{2} u(x, t)}{\partial x^{2}}+A|u(x, t)|^{2 m+1} u(x, t)=0$

Jika $m=0$ maka dari persamaan (62) didapatkan $\frac{\partial u(x, t)}{\partial t}+\frac{\partial^{2} u(x, t)}{\partial x^{2}}+A|u(x, t)| u(x, t)=0$

Kemudian memandang transformasi untuk $|u(x, t)|$ adalah $|U(\grave{u}, t)|$ dan berdasarkan transformasi Fourier yaitu persamaan (43) maka didapatkan

$|U(\grave{u}, t)|=\left|\int_{-\infty}^{\infty} \mu_{m}^{-i u ̀ t} u(x, t) d t\right|$

Berdasarkan persamaan (45) maka didapatkan modifikasi dari persamaan (63) adalah

$i \mathrm{u} U(\grave{\mathrm{u}}, t)+\frac{\partial^{2} U(\grave{\mathrm{u}}, t)}{\partial x^{2}}+A|U(\grave{\mathrm{u}}, t)| U(\grave{\mathrm{u}}, t)=0$

Persamaan ini dapat disederhanakan menjadi

$\frac{\partial^{2} U(\grave{\mathrm{u}}, t)}{\partial x^{2}}=(-i \mathrm{u}-A|U(\grave{\mathrm{u}}, t)|) U(\mathrm{u}, t)$

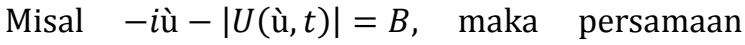
menjadi

$\frac{\partial^{2} U(\grave{\mathrm{u}}, t)}{\partial x^{2}}=B U(\grave{\mathrm{u}}, t)$

Selanjutnya analog dengan persamaan (18) maka persamaan (65) mempunyai solusi fungsi Airy dengan bentuk berikut:

$U(\grave{u}, t)=\frac{1}{\partial} \int_{0}^{\infty} \cos \left(\frac{\grave{\mathrm{u}}^{3}}{3}+B \grave{u}\right) d \grave{u}$

Substitusi $\quad B$ dengan $\quad-i$ ù $-A|U(\mathrm{ù}, t)|$ maka didapatkan

$U(\mathrm{ù}, t)=$

$\frac{1}{\partial} \int_{0}^{\infty} \cos \left(\frac{\grave{\mathrm{u}}^{3}}{3}+\left(\begin{array}{c}-i \mathrm{ù} \\ -A|U(\grave{\mathrm{u}}, t)|\end{array}\right)\right.$ ù $) d \grave{\mathrm{u}}$

Substitusi $\mid U($ ù, $t) \mid$ dengan persamaan (64) pada persamaan (66) maka didapatkan

$U(\mathrm{u}, t)=$

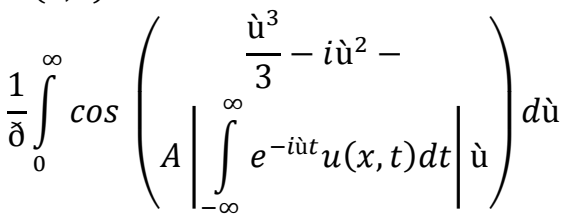

Dengan demikian persamaan (67) adalah solusi persamaan Airy (65) dan untuk mendapatkan solusi persamaan Schrodinger (63) maka transformasi Fourier yang terdapat pada persamaan (67) harus diinverskan dan analog 
dengan persamaan (44) maka persamaan (67) menjadi

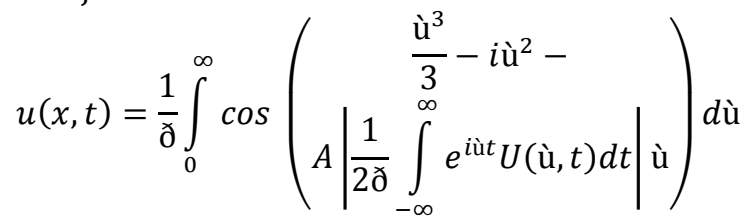

Diberikan kondisi awal adalah persamaan (55) dan (57) maka didapatkan

$u(x, t)$

$=\frac{1}{\partial} \int_{0}^{\infty} \cos \left(\begin{array}{c}\frac{\grave{\mathrm{u}}^{3}}{3}-i \grave{\mathrm{u}}^{2}- \\ A\left|\frac{1}{2 ð} \int_{-\infty}^{\infty} e^{i \grave{u} t} \grave{\mathrm{u}}^{2} d t\right| \grave{\mathrm{u}}\end{array}\right) d \grave{\mathrm{u}}$

Analog dengan persamaan (59) maka didapatkan hasil dari persamaan (68) adalah

$u(x, t)=\frac{1}{\partial} \int_{0}^{\infty} \cos \left(\frac{\grave{\mathrm{u}}^{3}}{3}-i \grave{u ̀}^{2}\right) d \grave{u}$

Dengan demikian persamaan (69) adalah solusi persamaan Schrodinger (63). Analog dengan proses kasus II maka solusi bagi persamaan berikut

$\frac{\partial u}{\partial t}(x, t)+\frac{\partial^{2} u}{\partial x^{2}}(x, t)+A|u(x, t)|^{2 m+1} u(x, t)=0$

adalah

$u(x, t)=\frac{1}{\partial} \int_{0}^{\infty} \cos \left(\frac{\grave{\mathrm{u}}^{3}}{3}-i \grave{\mathrm{u}}^{2}\right) d \grave{\mathrm{u}}$

\section{Bentuk Solusi Analitik Persamaan Schrodinger Nonlinier Dimensi Tinggi dengan Generalisasi Fungsi Airy}

Pada paparan sebelumnya didapatkan generalisasi bahwa pangkat $n$ dari modulus suku $A|u(x, t)|^{n} u(x, t)$ untuk setiap $n$ genap maupun ganjil menghasilkan solusi dengan bentuk yang sama dan hal ini memberikan kesimpulan bahwa solusi analitik persamaan Shrodinger nonlinier satu dimensi

$\frac{\partial u}{\partial t}(x, t)+\frac{\partial^{2} u}{\partial x^{2}}(x, t)+A|u(x, t)|^{n} u(x, t)=0$

adalah

$u(x, t)=\frac{1}{\partial} \int_{0}^{\infty} \cos \left(\frac{\grave{\mathrm{u}}^{3}}{3}-i \grave{u ̀}^{2}\right) d \grave{\mathrm{u}}$

Selanjutnya, analog dengan persamaan (3.12) maka persamaan Schrodinger nonlinier dua dimensi dapat dinyatakan sebagai berikut:

$\frac{\partial u}{\partial t}+\frac{\partial^{2} u}{\partial x_{1}^{2}}+\frac{\partial^{2} u}{\partial x_{2}^{2}}+A|u|^{2} u=0$

Dimana $u=u\left(x_{1}, x_{2}, t\right)$ dan memandang $U(\grave{u}, t)$ sebagai transformasi Fourier dari $u\left(x_{1}, x_{2}, t\right)$ dengan bentuk berikut:

$U(\grave{\mathrm{u}}, t)=\int_{-\infty}^{\infty} \int_{-\infty}^{\infty} e^{-i \grave{u}\left(t+x_{2}\right)} u d t d x_{2}$
Jika persamaan (71) diturunkan terhadap $t$ maka didapatkan

$$
\begin{aligned}
& \frac{\partial U(\mathrm{u}, t)}{\partial t}=\frac{\partial}{\partial t}\left(\int_{-\infty}^{\infty} \int_{-\infty}^{\infty} e^{-i \grave{u}\left(t+x_{2}\right)} u d t d x_{2}\right) \\
& =\int_{-\infty}^{\infty} \int_{-\infty}^{\infty} e^{-i \grave{u}\left(t+x_{2}\right)} u_{t} d t d x_{2} \\
& \left.=\int_{-\infty}^{\infty}\left[e^{-i \grave{u}\left(t+x_{2}\right)} u\right]_{-\infty}^{\infty}\left(-i \grave{u}\left(1+x_{2}\right)\right) e^{-i \grave{u}\left(t+x_{2}\right)} u d t\right) d x_{2} \\
& =\int_{-\infty}^{\infty} \int_{-\infty}^{\infty}\left(i \grave{u}\left(1+x_{2}\right)\right) e^{-i \grave{u}\left(t+x_{2}\right)} u t_{-} t d x_{2} \\
& =i \grave{u}\left(1+x_{2}\right) \int_{-\infty}^{\infty} \int_{-\infty}^{\infty} e^{-i \grave{u}\left(t+x_{2}\right)} u d t d x_{2} \\
& =i \grave{u}\left(1+x_{2}\right) U(\grave{u}, t)
\end{aligned}
$$

Untuk mendapatkan tranformasi Fourier dari $\frac{\partial^{2} U(\grave{u}, t)}{\partial x_{2}{ }^{2}}$ maka analog dengan proses persamaan (72) maka didapatkan

$\frac{\partial^{2} U(\grave{\mathrm{u}}, t)}{\partial x_{2}{ }^{2}}=-\grave{\mathrm{u}}^{2}(t+1)^{2} U(\grave{\mathrm{u}}, t)$

Selanjutnya memandang transformasi Fourier dari $\left|u\left(x_{1}, x_{2}, t\right)\right|^{2}$ adalah $|U(\mathrm{u}, t)|^{2}$ maka dapat dinyatakan

$|U(\mathrm{u}, t)|^{2}=U(\grave{u}, t) \bar{U}(\grave{u}, t)$

Berdasarkan persamaan (71) maka persa

(74) menjadi

$|U(\grave{\mathrm{u}}, t)|^{2}=\left(\int_{-\infty}^{\infty} \int_{-\infty}^{\infty} e^{-i \grave{u}\left(t+x_{2}\right)} u d t d x_{2}\right)$

$\left(\int_{-\infty}^{\infty} \int_{-\infty}^{\infty} e^{-i \grave{u}\left(t+x_{2}\right)} \bar{u} d t d x_{2}\right)$

Dengan persamaan (73) dan (74) maka persamaan (70) menjadi

$i \mathrm{u}\left(1+x_{2}\right) U(\grave{\mathrm{u}}, t)+\frac{\partial^{2} U(\grave{\mathrm{u}}, t)}{\partial x^{2}}-$

$\grave{\mathrm{u}}^{2}(t+1)^{2} U(\grave{\mathrm{u}}, t)+A|U(\grave{\mathrm{u}}, t)|^{2} U(\grave{\mathrm{u}}, t)=0$

Persamaan ini dapat disederhanakan menjadi

$\frac{\partial^{2} U(\grave{u}, t)}{\partial x^{2}}=$

$\left(\begin{array}{c}\grave{\mathrm{u}}^{2}(t+1)^{2}-i \mathrm{u}\left(1+x_{2}\right) \\ -A|U(\grave{\mathrm{u}}, t)|^{2}\end{array}\right) U(\grave{\mathrm{u}}, t)$

Misal $\grave{u}^{2}(t+1)^{2}-i \grave{u}\left(1+x_{2}\right)-A|U(\grave{u}, t)|^{2}=B$ maka persamaan (76) menjadi

$\frac{\partial^{2} U(\grave{\mathrm{u}}, t)}{\partial x^{2}}=B U(\grave{\mathrm{u}}, t)$

Berdaskan persamaan (18) maka solusi bagi persamaan (71) adalah

$U(\grave{u}, t)=\frac{1}{\partial} \int_{0}^{\infty} \cos \left(\frac{\grave{\mathrm{u}}^{3}}{3}+B \mathrm{ù}\right) d \grave{\mathrm{u}}$

Substitusi $B$ dengan $\grave{\mathrm{u}}^{2}(t+1)^{2}-i \mathrm{u}\left(1+x_{2}\right)-$ $A|U(\mathrm{ù}, t)|^{2}$ maka didapatkan 
$U(\mathrm{ù}, t)=$

$\frac{1}{\partial} \int_{0}^{\infty} \cos \left(\frac{\grave{\mathrm{u}}^{3}}{3}+\left(\begin{array}{c}\grave{\mathrm{u}}^{2}(t+1)^{2}- \\ i \mathrm{u}\left(1+x_{2}\right)-A|U(\mathrm{ù}, t)|^{2}\end{array}\right)\right.$ ù $) d \grave{u}$

Kemudian substitusi $\quad|U(\mathrm{u}, t)|^{2} \quad$ dengan persamaan (75) maka didapatkan

$U(\grave{u}, t)=$

$\frac{1}{\partial} \int_{0}^{\infty} \cos \left(\begin{array}{c}\frac{\grave{\mathrm{u}}^{3}}{3}+(t+1)^{2} \grave{\mathrm{u}}^{3}-i\left(1+x_{2}\right) \grave{\mathrm{u}}^{2} \\ -A\left(\begin{array}{c}\left(\int_{-\infty}^{\infty} \int_{-\infty}^{\infty} e^{-i \grave{u}(t+y)} u d t d x_{2}\right) \\ \left(\int_{-\infty}^{\infty} \int_{-\infty}^{\infty} e^{-i \grave{u}(t+y)} \bar{u} d t d x_{2}\right)\end{array}\right)\end{array}\right)$ ù

Persamaan (72) adalah solusi bagi persamaan Airy (71), sehingga untuk mendapatkan solusi persamaan Schrodinger (70) maka transformasi Fourier yang terdapat pada persamaan (72) harus diinverskan. Selanjutnya pandang persamaan (71) sebagai transformasi Fourier maka invers dari transformasi Fourier tersebut adalah

$\frac{1}{(2 ð)^{2}} \int_{-\infty}^{\infty} \int_{-\infty}^{\infty} e^{i \grave{u}\left(t+x_{2}\right)} U(\grave{\mathrm{u}}, t) d\left(\{\mathfrak{y}) d x_{2}\right.$

Dengan menerapkan invers transformasi Fourier (73) pada persamaan (72) maka didapatkan solusi bagi persamaan Schrodinger (70) adalah $u\left(x_{1}, x_{2}, t\right)=$

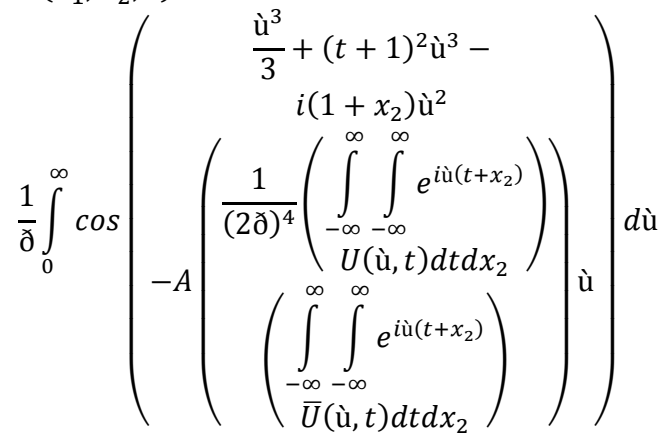

Berdasarkan persamaan (74) maka generalisasi fungsi Airy sebagai solusi persamaan Schrodinger nonlinier dimensi $n$ yaitu

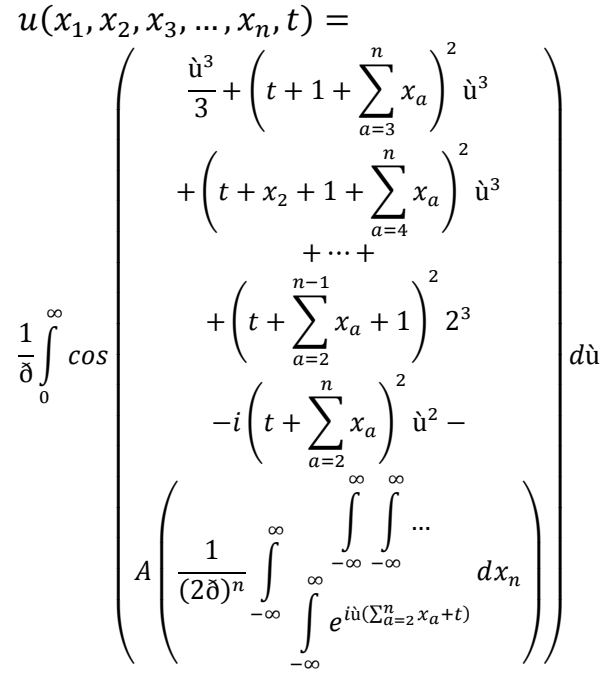

\section{PENUTUP}

Dari paparan pembahasan di atas dapat disimpulkan bahwa bentuk generalisasi fungsi Airy sebagai solusi analitik persamaan Schrodinger Nonlinier, yaitu: Bentuk generalisasi fungsi Airy ketika pangkat $n$ dari modulus persamaan Schrodinger Nonlinier

a. Jika $n$ genap yaitu $2 m$, maka didapatkan bentuk umum fungsi Airy untuk persamaan Schrodinger nonlinier adalah

$$
u(x, t)=\frac{1}{\partial} \int_{0}^{\infty} \cos \left(\frac{\grave{\mathrm{u}}^{3}}{3}-i \grave{u ̀}^{2}\right) d \mathrm{ù}
$$

b. Jika $n$ ganjil yaitu $2 m+1$, maka didapatkan bentuk umum fungsi Airy untuk persamaan Schrodinger nonlinier adalah

$$
u(x, t)=\frac{1}{\partial} \int_{0}^{\infty} \cos \left(\frac{\grave{\mathrm{u}}^{3}}{3}-i \grave{u ̀}^{2}\right) d \grave{u}
$$

Dengan demikian dapat diambil kesimpulan bahwa ketika pangkat dari modulus dianalisis dengan bentuk genap dan ganjil menghasilkan penyelesaian yang sama, yaitu:

$u(x, t)=\frac{1}{\partial} \int_{0}^{\infty} \cos \left(\frac{\grave{\mathrm{u}}^{3}}{3}-i \grave{\mathrm{u}}^{2}\right) d \mathrm{ù}$

Sedangkan bentuk umum ketika di analisis pada persamaan Schrodinger nonlinier dimensi tinggi maka didapatkan generalisasi fungsi Airy sebagai berikut:

$$
\begin{aligned}
& u\left(x_{1}, x_{2}, x_{3}, \ldots, x_{n}, t\right)= \\
& \frac{1}{\partial} \int_{0}^{\infty} \cos \left(\begin{array}{c}
\frac{\grave{\mathrm{u}}^{3}}{3}+\left(t+1+\sum_{a=3}^{n} x_{a}\right)^{2} \grave{\mathrm{u}}^{3} \\
+\left(t+x_{2}+1+\sum_{a=4}^{n} x_{a}\right)^{2} \grave{\mathrm{u}}^{3} \\
+\left(t+\sum_{a=2}^{+\cdots} x_{a}+1\right)^{2} \grave{\mathrm{u}}^{3} \\
-i\left(t+\sum_{a=2}^{n-1} x_{a}\right)^{2} \grave{\mathrm{u}}^{2}- \\
A\left(\begin{array}{c}
1 \\
\frac{1}{(2 ð)^{n}} \int_{-\infty}^{\infty} \int_{-\infty}^{\infty} \int_{-\infty}^{\infty} e^{i \grave{u}\left(\sum_{a=2}^{n} x_{a}+t\right)}
\end{array}\right) d x_{n}
\end{array}\right) d \mathrm{u}
\end{aligned}
$$

\section{DAFTAR PUSTAKA}

[1] Agarwal, Ravi P. dan O'regan, Donal. 2009. Ordinary and Partial Diffreential Equations. New York: Springer.

[2] Polyanain, A. D. dan Zaitsev. 2004. Handbook of Nonlinear Partial Differential Equatiuons. New York: Chapman \& Hall. 
[3] Purcell, Edwin J. dan Dale Varberg. 1999. Kalkulus dan Geometri Analitik. Jilid 2. Jakarta: Erlangga.

[4] Purwanto, Agus. 2003. Fisika Matematika 1\&2. Surabaya: ITS Press.

[5] Ross, Shepley L. 1984. Differential Equations. Third Edition. New York: John Wiley\&Sons. Inc.

[6] Sudirham, Sudaryatno dan Ning Utari. 2010. Mengenal Sifat-Sifat Materi. Bandung:: Darpublic.

[7] Valle, Oliver dan Manuael, Soares. 2004. Airy Functions and Applications to Physics. London: Imperial College Press. 